\title{
AUTHORITARIANISM IN EUROPE INE THE TWENTIETH CENTURY: A POLITICAL-SCIENCE ANALYSIS OF THE CHARACTERISTICS OF THE POLITICAL SYSTEM (PART 1)
}

\begin{abstract}
The article is a political-science analysis of authoritarianism as a political system, which was an alternative to democracy and totalitarianism in Europe in the twentieth century. It presents the theoretical determinants of the problem such as disputes over definitions and the definition of the concept of authoritarianism, the subjective and chronological scopes of the use of the term, and the origin of the definition. In his empirical studies on specific instances of the occurrence of dictatorship in Europe, the author used the term "authoritarian syndrome". Seven constitutive elements of the authoritarian syndrome were analyzed: 1) the sovereign as the fundamental institution of State power; 2) coup d'état - the character, ideal type, and its specific variants; 3 ) the formula of legitimation of State power, including inter alia the character of ways of legitimizing authority, and the "drama of legitimation" after the dictator's death; 4) limited autonomy of society, manifested in the depoliticization of society and in the growing influence of the State on social life with some autonomous spheres being retained; 5) consolidation of State power; 6) the traditionalist axiological order and its sources; 7) the authoritarian camp. Four of seven elements of the authoritarian syndrome were analyzed in first part of this article: the sovereign, coup d'état, the formula of legitimation and limited autonomy of society.
\end{abstract}

Keywords: Authoritarianism, Political System, Twentieth Century, Political Thought.

\section{INTRODUCTORY REMARKS}

The term "authoritarianism" can be used to describe a political system or movement, and political thought ${ }^{2}$; its name derives from Latin auctoritas, which denotes political power exercised in the State, based on moral authority and vested with special powers to make strategic decisions not bound by legal norms. The authoritarian system in the twentieth century was one of the three model solutions - apart from democracy and totalitarianism - for the organization of public space that were first described in the studies by Eric Voegelin (1936) and Juan José Linz (1964) ${ }^{3}$, who presented the concept of

\footnotetext{
${ }^{1}$ Dr hab. Waldemar Paruch prof. UMCS, Wydział Politologii, UMCS w Lublinie, Plac Litewski 3, 20 - 080 Lublin, e-mail: wparuch@ @2.p1

${ }^{2}$ For a similar view see J.W. Borejsza, Szkoty nienawiści: Historia faszyzmów europejskich 19191945, Wrocław-Warszawa-Kraków 2000, p. 126.

${ }^{3}$ E. Voegelin, Der autitäre Staat, Vienna 1936, passim; J.J. Linz, An Authoritarian Regime: Spain, [in:] Cleavages, Ideologies and Party Systems, eds A. Allardt, Y. Littunen, Helsinki 1964, pp. 291341; see also S.G. Payne, The Franco's Regime, Madison 1987, passim.
} 
so-called authoritarian regimes to differentiate them from totalitarian and democratic ones. In the interwar years authoritarianism became almost a political standard for the Central-European states between Germany and Russia, running meridionally from Finland to Turkey. It was adopted in all states in that part Europe, even - contrary to popular opinion - in Czechoslovakia. The Second Czechoslovak Republic, which existed from October 1938 to March 1939, i.e. between the Munich conference and the liquidation of Czechoslovakia's independence, exhibited the traits of an authoritarian regime ${ }^{4}$. This type of system also functioned in Western Europe in different times: in Spain, Portugal and the French State (the so-called Vichy France regime, which existed during Word War II).

Authoritarianism was based on the belief that public institutions exercising political authority should be recognized by society as carriers of historically significant values. The rational and emotional recognition of these values was intended as a way of maintaining the stability of political and social structures endangered by crisis, while the attitude to the values in question was the basic factor that determined competition in public space, and imposed upon it a specific internal organization and political diversity. Such views on authority attributed to political power tended to be a source of significant restrictions in the political system - they can be observed in relation to three entities or actors: society as a whole, all subordinated individuals, and each politician who participated in governing according to authoritative norms. In Anna Mikołejko's view, authority so defined can be understood in two ways: on the one hand as one of the means of subordinating individuals and society to the values advocated by the governing bodies, and on the other hand - as an expression of social needs manifested under specific historical circumstances ${ }^{5}$.

\section{THE SOVEREIGN - THE PRINCIPAL INSTITUTION OF STATE}

\section{POWER}

The principal institution of State power in authoritarianism was the sovereign ${ }^{6}$, which decided the fundamental political issues. In terms of the formal aspect, three situations can be distinguished. In the first variant, the role of the sovereign was exercised by the individual that held the supreme office in the State: that of king, regent, president, chief of State, or headed the government as prime minister (chancellor). The assumption of one of the aforementioned offices occurred as a result of a coup d'état that paved the way to

\footnotetext{
${ }^{4}$ This was discussed inter alia by: J. Rataj, O autoritativní národní stát: Ideologické proměny české politiky v Druhé Republice 1938-1939, Praha 1997, passim; J. Tomaszewski, Czechosłowacja, Warszawa 1997, pp. 77-78.

${ }^{5}$ A. Mikołejko, Poza autorytetem?: Społeczeństwo polskie w sytuacji anomii, Warszawa 1991, p. 10 et seq.

6 The term "leader", when used to refer to the authoritarian system, resulted in adverse consequences observable in the studies which suggest that there are two similarities: first, between authoritarianism and totalitarianism in its fascist version; second, between the powers of the leader in the totalitarian State and the powers of the dictator in the authoritarian State. Jerzy Holzer showed that the two institutions were very far apart in legal, functional and systemic terms. J. Holzer, System faszystowski a autorytarny: Uwagi polemiczne, "Acta Universitatis Wratislaviensis”, Studia nad faszyzmem i zbrodniami hitlerowskimi. Faszyzm - teoria i praktyka w Europie (1922-1945) $1977 / 3$, p. 272.
} 
carry out changes in the political system. This is what happened in most of the authoritarian states - in Austria, Hungary, and in Baltic and Balkan states.

The second variant consisted in the exercise of the sovereign's powers by a politician who influenced the State organs without being the holder of the supreme office within the adopted political solutions. This post was held in Poland both by Marshals Józef Piłsudski and Edward Śmigły-Rydz. Similar solutions were adopted in Portugal (Antonio de Oliveira Salazar), Rumania (General Ion Antonescu), Greece (General Ioannis Metaxas), and in Spain (General Francisco Bahamonde Franco).

The third solution, however, was definitely different: sovereign power in the State was taken over by a group of persons who formed a special council that functioned openly or in secret.

Konstanty Grzybowski defined the sovereign with the term moderator imperii (Regent), deriving its origin from political decisions taken in fairly remote history ancient and medieval. The sovereign would be the guardian of the constitution: by using his decision making powers and breaking legal norms, he would stabilize the existing axiological and political order under conditions of threat, that is when the State organs, vested with potestas powers, became helpless in the face of the complex situation and the scale of danger. The guardian of the political system exercised supervisory authority referred to as auctoritas ${ }^{7}$. This produced substantial consequences. The actions of the sovereign were not based on positive legal norms (the letter of the law) but had a nonlegal and supralegal character as well as being meant to protect the existing traditional order (the spirit of the law) against the destroyers of it, who took advantage of legalism of the law, thus becoming destructive forces. In Grzybowski's opinion the sovereign's behavior was restricted by "certain contents, concepts, and certain legal principles". Therefore it is the return to "the myth of supreme values, with the ruler being responsible for their protection" ${ }^{\prime 8}$. Acting in the name of these values the dictator virtually became (regardless of the constitutional provisions) the sole source of authority for the organs of the State. In many authoritarian states the political status of the dictator was justified on religious grounds.

In the interwar years this concept of the sovereign was restored to contemporary political thinking by Carl Schmitt in the doctrine of decisionism ${ }^{9}$. Schmitt recognized that only the sovereign as a special supervisory organ could be the guarantor of the political order, responsible for the protection of the State's existence against both internal dangers and those arising from the international environment. It was to him (and solely to him) that Schmitt ascribed political empowerment/actorship, whose underlying characteristic

\footnotetext{
${ }^{7}$ See T. Żyro, Autorytet a autorytaryzm: Kilka uwag doktrynalnych, [in:] Adaptacja - reforma stabilizacja: Przestrzeń publiczna we współczesnych systemach politycznych, eds T. Koziełło, P. Maj, W. Paruch, Rzeszów 2010, pp. 242-244.

${ }^{8}$ K. Grzybowski, Moderator imperii, "Czasopismo Prawno-Historyczne" 1963/2, pp. 97-124. The category of the guardian of the constitution in its political-science aspect became the object of interest on the part of Franciszek Ryszka. See F. Ryszka, Państwo stanu wyjatkowego: Rzecz o systemie państwa i prawa Trzeciej Rzeszy, 3 ed., revised and amended, Wrocław-WarszawaKraków-Gdańsk-Łódź 1985, pp. 57-60.

${ }^{9}$ C. Schmitt, Teologia polityczna i inne pisma, Warszawa 2012, pp. 55-76. See R. Skarzyński, Od chaosu do ładu: Carl Schmitt i problem tego co polityczne, Warszawa 1992, passim.
} 
was to organize public space. This involved the mythologizing of the person of the leader, who was seen both as the embodiment of history and native traditions and as a thrifty manager concerned about increasing the common good as well as the ruler endowed with extraordinary personal traits (charisma) that make him predestined to exercise government. This was frequently expressed through special titles: caudillo Francisco Franco, vadonis Karlis Ulmanis, or conducatorul Ion Antonescu, atatürk Mustafa Kemal.

The sovereign acted on behalf of the absolute being recognized as the supreme value that put the political reality in order and determined political rivalry. These absolute beings and values at the same time could be the State or nation, which had their own goals, interests, will, and law. In the first place the sovereign molded the absolute values into the form of a concrete role model, which enabled consolidation of the society around the implementation of specific goals. With regard to the State these were most often the protection of independence, maintenance of frontiers and stability of the political order. If the nation became the most precious value, then the aim of political activity was to strengthen national existence, secure the assets or protect cultural identity. In the second place, the sovereign would implement national or State interests in the current policy as well as express and interpret the will of and exercise sovereign rights attributed to the State and nation.

The State was regarded as the most important value in the authoritarian system established in Poland, Spain, Austria and Yugoslavia, and in Hungary, while this role was played by the concept of "nation" in the Baltic states and Turkey ${ }^{10}$. In the former type of states, the decisions taken, including the power takeover, were explained by invoking State interests. Different reasons were adduced, the State being perceived as a force capable of overcoming anarchy, chaos and internal danger; as a factor being in contradiction with party particularism; as a regulator of ethnic conflicts; and as an expression of the society's political unity going beyond regional and ethnic separatism. In the latter group of countries, national reasons were given to the public, first of all the defense of the ruling and dominant nation against dangers from either ethnic minorities or neighboring countries, and the striving to create a new nation (Yugoslav or Czechoslovak). Nation was shown in the propaganda as the most important actor in history, oriented towards defending its own independent State with an explicit ethnic (linguistic, cultural) identity ${ }^{11}$.

\footnotetext{
10 See T. Paluszyński, Walka o niepodległość Łotwy 1914-1921, Warszawa 1999, passim; J. Lewandowski, Historia Estonii, Wrocław-Warszawa-Kraków 2002, passim; K. Poznańska, Republika Turecka: Türkiye Cumhuriyeti, Warszawa 1977, pp. 33-34.

11 See P. Łossowski, Rzady dyktatorskie $w$ państwach battyckich 1926-1940: Studium porównawcze, "Acta Universitatis Wratislaviensis", Studia nad faszyzmem i zbrodniami hitlerowskimi 1982/8, pp. 20-21; idem, Ideologie reżimów autorytarnych (kraje battyckie 19261934-1940), [in:] Dyktatury w Europie Środkowo-Wschodniej 1918-1939: Konferencja naukowa w Instytucie Historii PAN 2-3 XII 1971, ed. J. Żarnowski, Wrocław-Warszawa-Kraków-Gdańsk 1973, pp. 129-131; A. Wielomski, Doktryna El Caudillaje na tle XIX- i XX-wiecznej hiszpańskiej tradycji politycznej, "Acta Universitatis Wratislaviensis", Studia nad faszyzmem i zbrodniami hitlerowskimi 1999/22, p. 166; F. Ryszka, Państwo stanu wyjątkowego..., pp. 66-67; idem, Państwo autorytarne, [in:] Dyktatury w Europie Środkowo-Wschodniej..., pp. 119-120; M. Koźmiński, Nacjonalizm, mniejszości narodowe a reżimy dyktatorskie w Europie Środkowo-
} 
The sovereign's decisions were not restricted by statutory law, consequently the sovereign was not held politically or constitutionally responsible because the essence of the legal order in the authoritarian system was that there was a category of State decisions made by the sovereign for which no one was accountable. Grzybowski wrote, "A characteristic of the sovereign is that he is above and beyond any regulation [...]"12. By contrast, other State authority agencies in the authoritarian system (the government, representative bodies, the system of justice, local government structures, armed forces) were expected to operate, on the one hand, within the bounds of law, but, on the other hand, also to fulfill the will of the sovereign in crisis situations. However, the general rule in the authoritarian State was that State authority agencies should function within the rule of law. Only in exceptional cases does the dictator "order all laws to be silent and suspend superior authority for a while", but he is not the creator of new law. It is also assumed that the authoritarian order should be temporary; its creators first aim at legalizing and then developing a new legal order ${ }^{13}$.

Three fundamental matters depended on the sovereign. First, the sovereign formed an alternative-free concept of the axiological order: the division into good and evil, truth and falsity, and into order and chaos. He imposed the interpretation of events, dividing them into the positive ones that should be recorded in the tradition and whose social image should be strengthened, and the negative ones embodying and symbolizing dangers that should be condemned and shown as manifestations of evil. Second, the guardian of the constitution defined the foundations of a new State order aimed at overcoming crises. $\mathrm{He}$ made decisions concerning the procedure for and pace of the establishment of a new political order in the State. Third, the sovereign determined relations between political actors. He divided them into allies and foes on the internal arena. As the fullest exponent of the authority of State power he would assess public behaviors undertaken by individuals, guided by the system of norms based on the axiological order he himself imposed.

\section{COUP D'ÉTAT}

The authoritative road to power consisted in staging a coup d'état and overthrowing the democratic order ${ }^{14}$. Changing the public order by force was most often effected as a

Wschodniej w latach 1918-1939, [in:] Dyktatury w Europie Środkowo-Wschodniej..., pp. 97-107; J. Kochanowski, Wegry: Od ugody do ugody 1867-1990, Warszawa 1997, p. 62 et seq.

${ }^{12}$ K. Grzybowski, Od dyktatury ku kompromisowi konstytucyjnemu, Kraków 1930, p. 11; see D. Górecki, Pozycja ustrojowo-prawna Prezydenta Rzeczypospolitej i rządu w ustawie konstytucyjnej z 23 kwietnia 1935 roku, Łódź 1992, p. 49.

${ }^{13}$ K.W. Kumaniecki, Nadzwyczajne urzędy (z prawniczych rozmyślań nad dyktatura), Kraków 1928, pp. 9-10, 13. Piłsudski's adherents, at least when the Commandant was alive, were aware of the transitional character of the system they established. In the Sejm, it was Bogusław Miedziński who assured that "[...] we have in Poland a man who is the arbiter regardless of what post he holds and that this encourages us to build a stable political system. [...] we know that these are passing circumstances, excellent for our generation". Sprawozdanie stenograficzne z 142 posiedzenia Sejmu Rzeczypospolitej [Shorthand report of the Sejm session, $3^{\text {rd }}$ term], 23/24 march 1935, p. 148; see also Stanistaw Car - polska koncepcja autorytaryzmu, ed. J.M. Majchrowski, Warszawa 1996, pp. $17,21$.

${ }^{14}$ See A. Salazar, Rewolucja pokojowa, Warszawa 2013, passim. 
result of competition between different factions of the political elite, without decisive participation of the masses and without an external factor ${ }^{15}$. Classical coups d'état were staged in Poland, in Portugal and in Lithuania in 1926, in Bulgaria in 1923 and 1934, in Rumania in 1938 and 1940, in Estonia in 1934, in Yugoslavia in 1929, and in Greece in 1936. The Hungarian, Spanish, and French events can be regarded as exception in this respect. The seizure of power by Admiral Miklós Horthy in 1919 and by General Francisco Franco y Bahamonde in 1936-1939 took place during a civil war, whereas the takeover of power by Marshal Philippe Pétain in 1940 was the result of defeat in war. The course of fighting and the ultimate success was decided not only by the attitude of the respective armies but also by interference of the international community (the allied armies in Hungary, and the German-Italian alliance in Spain and France).

The ideal type of coup d'état in the authoritarian spirit was the pronunciamento, or the rebellion of a commander with a widely recognized record of previous merits, who used his loyal troops in order to defend the most important values, traditions, and order against politicians who legally make bad law or implement wrong decisions as constitutional officials. The pronunciamento could have either a soft form (a threat to use violence) or hard (civil war). In the interwar years the best known and most inspiring historical concretization of military coup d'état was the pronunciamento by General Miguel Primo de Rivera, which was carried out in Spain in 1923. Most often, the pronunciamento was seen as a technical task coming down to organizing the action of well prepared troops rather than a social challenge implemented with the participation of large social groups ${ }^{16}$. This approach to the problem was propagated by Curzio Malaparte in his popular book of 1931: Coup d'État. The Technique of Revolution ${ }^{17}$.

The prime mover and the driving force of the coup was the military ${ }^{18}$. Henryk Bułhak's studies show that Latvia was an exception in this respect. In this country the military did not take part in the coup d'état, which was carried out on 15/16 May 1934, the main driving force being the paramilitary organization of the aizsargs. By involving the armed forces, those who staged particular coups d'état could appeal both to the State features of the military (the element of State cohesion, guarantor of the State's sovereignty and territorial integrity) and the national characteristics of the army (ethos of the nationalliberation force, ethnically homogeneous character, a factor of social advancement). In the authoritarian system the army was granted a special distinct status with such characteristics as 1) direct subordination to the sovereign; 2) separation from the

\footnotetext{
${ }^{15}$ For a comparative analysis of a coup d'état, revolution, and putsch, see Z. Drag, Mechanizmy zmiany systemów politycznych, "Zeszyty Naukowe Akademii Ekonomicznej w Krakowie", Prace z Zakresu Nauk Politycznych 1998/500, pp. 75-88.

${ }^{16}$ W. Królikowski, Hiszpania 1923: Pronunciamento generała Primo de Rivery, [in:] Przewroty $i$ zamachy..., pp. 97, 108; M. Tuñón de Lara, J.V. Baruque, A.D. Ortiz, Historia Hiszpanii, Kraków 1997, pp. 534-536; W. Brodzikowski, J. Łoskoczyński, Franco, generat wielkiej misji, Warszawa 1999, pp. 14-15; L. Mularska-Andziak, Dyktatura generała Primo de Rivery a hiszpańskie tradycje imperialne 1923-1930, Warszawa 1999, passim.

${ }_{17}$ On the role of Malaparte's achievements as a writer in the development of authoritarian thought see J.W. Borejsza, Mussolini byt pierwszy..., Warszawa 1979, p. 412.

${ }^{18}$ More on the involvement of the military in authoritarian coups see H. Bułhak, Rola wojska $w$ przewrotach autorytarnych, [in:] Dyktatury w Europie Środkowo-Wschodniej..., pp. 143-150.
} 
authoritarian movement and administration; 3) a factor stabilizing the system against various threats; 4) a privileged economic position and prestige; 5) a preparatory path for participation in political life and work in the administration. When staging a coup d'état no attempts were made to involve large social groups, or use the structures of own party (in Poland, Marshal Piłsudski did not create any party before May 1926), party militia or State (or political) police ${ }^{19}$.

The dictator often attached great significance to the legitimation of the coup d'état. The recognized procedure was either to issue a special, one-time political document or to introduce a new political order. The former solution was adopted in Poland, Spain, Portugal and in Hungary, in the French (Vichy) State and in the Baltic countries. In the Kingdom of Hungary this document was the resolution of the Parliament of 1 March 1920, which gave Admiral Horthy the office of Regent. Piłsudski recognized as the act of legitimation his election to the office of President by the National Assembly while in Spain the commission of lawyers declared on 21 December 1938 that General Franco was the legal continuator of the Republic which existed in 1931-1936. By contrast, Marshal Pétain was elected Chief of the French State, while the Latvian, Lithuanian, and Estonian dictators were entrusted with the office of the President. A distinctly different form of legitimation was adopted in Albania, Greece, and in Yugoslavia. In the first two states, the introduction of the monarchist form of government was proclaimed - that of Ahmed Zogu in 1929 and of George II in 1936. In the Serbian-Croatian-Slovene State, however, the name of the monarchy was changed, having been given a new form of organization ${ }^{20}$.

Two goals were usually set for the coup d'état to be implemented simultaneously. First, the army was expected to overthrow the democratic order, which the coup organizers regarded as a political system detrimental to the State and/or nation. Second, the goal was also to safeguard the State against the threat from totalitarian movements (communist and fascist) inspired from without and enjoying foreign support. The proportions between the two motives were distributed differently in individual states. In Poland, Marshal Józef Piłsudski, Professor Antonio de Oliveira Salazar and General Ioannis Metaxas in Greece, first of all overthrew democratic governments. In Hungary, Spain, Bulgaria, and in Austria the authoritarian camp opposed both the communists and the radical Left (in the first place) and the fascists (in the second place). In 1934 Antanas Smetona's men in Lithuania, and General Johan Laindoner's and Konstantin Päts's formations in Estonia fought against the radical Right, and in Latvia in 1934 Karlis Ulmanis's camp defeated the extreme Left. In Portugal and in Rumania the dictators (Antonio de Oliveira Salazar, Carol II and General Ion Antonescu) fought mainly against the fascist threat ${ }^{21}$. The authoritarian governments thwarted most political plans of not only the international communist movement controlled by the Soviet Union but also those of the domestic fascist groups such as the Iron Guard in Romania, Falange in Spain, the Arrow Cross Movement in Hungary, the Veterans League (wabs) in Estonia, and the Austrian Nazis (Hitlerites).

\footnotetext{
${ }^{19}$ For more see A. Misiuk, Stużby specjalne II Rzeczypospolitej, Warszawa 1998, p. 123 et seq. ${ }^{20}$ A. Wielomski, op. cit., p. 181; J.W. Borejsza, Szkoty nienawiści..., pp. 129, 146-148.

${ }^{21}$ See J. W. Borejsza, Szkoty nienawiści..., passim; P. Machcewicz, Frankizm: Analiza ruchu politycznego, "Magazyn Historyczny. Mówią Wieki” 1990/8, pp. 29-31.
} 
A coup d'état as a way of taking over power was justified by internal and external threats and it stemmed from the belief that it was impossible to reach a political compromise because of the escalation of conflicts within the elite that had the characteristics of a clearly axiological dispute. However, reasons for coups d'état were far more complicated than this justification ${ }^{22}$.

The first factor: the undeniably most important role was played by the crisis of organs of State authority (the parliament, government, the system of justice, and local government) and the malfunctioning mechanism of democracy in the parliamentary version. The causes of crises should be sought in the development of the so-called political blind side, which arose as a result of the attitude and activities of the groups opposing the existing political, social and territorial order. These included the majority of parties representing ethnic minorities, totalitarian movements (communist and fascist) and the parties of the radical Left and the national Right. In the democratic system they were isolated and irrelevant parliamentary groups, which often paralyzed the work of the parliament and made it impossible to form a stable government coalition. That situation produced in the social consciousness a strong conviction about the disintegration of the democratic system, thus endangering the most important values: State and nation. This was accompanied by the emergence of many circles among the political elite that saw the chances of overcoming crises not in democratic procedures but in challenging them because that part of the elite recognized democracy as the cause of the resultant situation.

The second factor: military coups were staged most often in European states, either in those situated in the area lacking international security, or in those facing the need to redefine their own international position. The former variant applied to the Central European area because the Versailles order legitimized in this part of the Continent a new political and territorial map, whose main elements were the new or transformed states. However, the new order was not stable in territorial terms, which stemmed from mutual border claims of Central European states and the imperialist plans of the neighboring powers (the Soviet Union, Germany, and Italy) towards this region. The latter variant concerned Western European states - Spain, France, and Portugal - whose existing political status was endangered as a result of the breakup of their colonial empires and/or defeat in war. Some of the political forces decided to defend the previous positions of their countries as powers and imperial relics by choosing the authoritarian option.

In the opinion of many ideologists of authoritarianism, external causes were directly linked to the negative condition of society plunged into a moral collapse brought about by wars and the adoption of totalitarian solutions, and enfeebled by the disintegration of traditional bonds and social balance. In this respect, special role was attributed to the national-ethnic issues. The idea of the right of nations to self-determination advocated by US politicians after the Great War became extremely dangerous for the countries in Central Europe. In this part of the Continent, ethnic-cultural nations emerged, which also

\footnotetext{
${ }^{22}$ For the causes of the coups see: P. Łossowski, Rządy dyktatorskie..., pp. 16-17; Przewroty i zamachy stanu..., passim; A. Wielomski, op. cit., pp. 190-191; J. Żarnowski, Reżimy autorytarne w Europie Środkowej i Południowo-Wschodniej w okresie międzywojennym - analogie i różnice, [in:] Dyktatury w Europie Środkowo-Wschodniej..., pp. 25-29; J. Lewandowski, op. cit., pp. 194196; T. Wituch, Historia Portugalii w XX wieku, Pułtusk 2000, pp. 79-84.
} 
meant that the issue of minorities was generated, being used conveniently not only by irredentist movements but also by the communists and the Nazis Hitlerites. The twentieth century witnessed further attempts to build a national consciousness based on the precedence of political bonds over ethnic ones. These objectives can be found in the programs advanced by Marshal Piłsudski in Poland, by Professor Salazar in Portugal and by Admiral Horthy in Hungary as well as in the Yugoslav and Czechoslovak ideas, or in the vision of a single Spain implemented by General Franco. Difficulties with the execution of these projects strengthened the conviction that the democratic State was helpless in the face of ethnic problems and decentralist forces. Giving up the conception of forming political nations in Central Europe, many politicians turned towards nationalism in the ethnic sense. This turn resulted in the conviction that it was the Poles, Hungarians, Czechs, and Serbs who should be the hosts in their countries, subordinating other ethnic minority communities to their control.

The third factor - the democratic order established in many countries after the Great War "clashed" with social and economic expectations articulated by large social groups (peasants, workers, middle classes). Faced with the scale of demands and their mutual collision (for example agriculture versus industry), the liberal market economy that accompanied democracy was unable to meet social expectations fueled, in addition, by communists and fascists. Standards of economic efficiency measured in terms of production costs, its quality and quantity, and by the level of public debt, were in gross contradiction to many social-economic slogans, e.g. demands for radical and speedy agricultural reform, the spread of ownership, respect for social rights, execution of the constitutional guarantees of free availability of many services (in education, health, and infrastructure). Seeing no chances of curbing social demands within the democratic and market economy order, many politicians and economists adopted as the grounds for an authoritarian coup the belief that it was possible to achieve economic goals by giving up democracy and strengthening the State's influence on economic processes. The authoritarian dictator provided better guarantees than the parliament and democratic government that social claims would not destroy the economic order and that State authorities would endeavor to maintain order in the economy, isolating it from experiments carried out in the Soviet Union and the Third Reich.

With time, the coup d'état in authoritarian political thought was mythicized, the assessment of it being the most important criterion for the division of participants in public life into allies and foes. This practice in Poland was lucidly described by Tadeusz Hołówko, "If you condemn the May coup d'état, then there is nothing to debate on because in this case there is a gap between us, which we cannot bridge. For I belong to the camp which regards the May coup as a historical necessity [...] and the perpetrators of this coup regard this act as one of the greatest among His [Piłsudski's - W. P] many lasting services for the nation" ${ }^{\text {} 23}$. The direct objective of coups was to replace the ruling elite but without the participation of non-elite, and to stabilize public life. From the perspective of the past twentieth century, we can assume that in many cases this goal was achieved. In reference to Central Europe, we accept the assessment by Piotr Łossowski that the states in this part of the Continent which were under the authoritarian rule for most of the

\footnotetext{
${ }^{23}$ T. Hołówko, Ostatni rok, Warsaw 1932, p. 19.
} 
interwar years " $[\ldots]$ at that time proved their viability and the ability to exist independently and as separate entities. This negated the so frequent voices of doubt and skepticism claiming that these states would be incapable of independent political and economic existence" ${ }^{24}$.

\section{THE FORMULA OF LEGITIMATION OF STATE POWER}

In authoritarianism we can distinguish a specific formula of the legitimation of State power $^{25}$, constituted by the ways of conservative legitimation: decisionist, axiological, technocratic, systemic and charismatic. The camps exercising authoritarian power used all these ways, giving them a historically determined form ${ }^{26}$. In the authoritarian system those governing deliberately and consciously avoided recourse to general elections as the legitimation of the power they exercised in the State. The explanation can be found in the words of Stanisław Car of 11 December 1933, "Voting is a tyranny of numbers prevailing over reason" 27 . In accordance with the essence of authoritarianism, recourse to the procedure of free elections did not fulfill the function of legitimation, the elections being no way in which to create State authority. The authoritarian formation was not established in order to win elections and thereby contribute to the formation of parliamentary-majority governments. A reliable comment on this issue can be Marshal Piłsudski's statement in his interview with Bogusław Miedziński on 24 October 1930, "Naturally, and you, and everyone can easily understand that both I and all those who closely cooperate with me cannot possibly lose [...] and the matter I submitted for the elections cannot entail any possibility of me losing it",28.

The goals set for political organizations of the dictator's followers, which took part in elections, depended on the character of the process. Two variants can be generally distinguished. The first variant: if legal provisions created the conditions for political struggle with the opposition, the election structures of the ruling camp were to implement tactical tasks assigned by the leaders of the camp. The purpose of the assignments was above all to be conducive to a strong polarization of the political scene: the authoritarian camp versus the anti-systemic opposition, clearly indicating both the winner and election

${ }^{24}$ P. Łossowski, Europa Środkowo-Wschodnia XX wieku - triumf dezintegracji?, "Dzieje Najnowsze" 1996/1, p. 56. A different assessment was offered by Janusz Żarnowski - J. Żarnowski, op. cit., pp. 37-38.

${ }^{25}$ A legitimation formula is a set of arguments, actions, procedures and symbols used in a political system to achieve the legitimacy of State power. The definition is based on the analysis of the problem of legitimation carried out in: W. Sokół, Legitymizacja polityczna, [in:] Wprowadzenie do nauki o państwie i polityce, eds B. Szmulik, M. Żmigrodzki, Lublin 2002, pp. 220-230, 239-241; idem, Legitymizacja systemów politycznych, Lublin 1997, pp. 77-92. The list of basic literature on the ways of legitimation see also: idem, System autorytarny i jego legitymizacja, [in:] Spoteczeństwo - Państwo - Władza, ed. M. Żmigrodzki, Lublin 1995, pp. 113-128; Wprowadzenie do nauk politycznych, M.G. Roskin et al., Poznań 2001, pp. 17-22.

${ }^{26}$ For a theoretical analysis of the problem of legitimation in authoritarianism, regrettably without any sources, see W. Sokół, System autorytarny i jego legitymizacja..., pp. 113-128.

${ }^{27}$ S. Car, Na drodze ku nowej konstytucji, Warszawa 1934, p. 11.

${ }^{28}$ J. Piłsudski, Pisma zbiorowe: Wydanie prac dotychczas drukiem ogłoszonych, vol. 9, Warszawa 1938, p. 256. 
limitations. Then the elections had the character of a plebiscite, which consolidated the dichotomous division of participants in political life. The other variant: if elections were reduced to competition only between the dictator's adherents of different orientations, their organizations would participate in determining the composition of the legislative chambers, whose responsibility was to make law.

The first form of authoritarian legitimation was reference to the need to defend the supreme value, which was the State or nation endangered by the unfavorable development of international relations, internal crisis or the helplessness of society facing the inefficiency of the democratic system. Thus, the grounds for axiological legitimation was the conviction that the political system should be based on a value which, in Vilfred Pareto's view, can be 1) an expression of tradition 2) the result of reasoning, 3) an appeal to emotions ${ }^{29}$. Under conditions of danger the constitutive sovereign of the authoritarian system took actions outside the law; he was authorized by the State to save its existence and interests. In authoritarian political thought filled with nationalist themes the protection of State was in this context the best means of achieving national interests. The so understood tasks implemented by the sovereign had a historical dimension - he ensured a balance between moral principles and the requirements of political reality, between transcendent values and social needs and expectations.

The second form of legitimation is the use of the symbol of revolution, which would invest the system with a moral order and the feature of efficiency, and endow politics with an ethical dimension in the form of individual extralegal responsibility for taking decisions. After a coup d'état, politics would not only gain a new quality but also express the implementation of a historic mission: change the society's consciousness and its attitude towards the State, which would result in the achievement of goals of historical significance. In the first place, the objective was to pacify the situation and establish order, and in the second place, to slowly draft and gradually implement well-thought-out reforms that would strengthen the State and nation, thus protecting them against a repeated crisis.

The third form of justifying the legitimacy of power, used by authoritarian movements, was charismatic legitimation, which consisted in emphasizing the sovereign's political leadership. Adherents of dictators attributed to them the features characteristic of charismatic leaders, inter alia power and moral strength, ability to act in a historic and mythical dimension exempt from political assessment, and mythicization and personification of "good political order"30. The leader seemed to be an eminent figure, who combined the sphere of values, molded as a result of historical development, with a specific political reality, which required taking decisions not only effective and accurate but also consistent with the axiological order. The dictator's associates believed that the

\footnotetext{
${ }^{29}$ A. Mikołejko, op. cit., p. 21.

${ }^{30}$ See T. Biernat, Fenomen władzy charyzmatycznej - ludzka potrzeba transcendencji (Refleksja antropologiczna), [in:] Antropologia polityki, z. 2, Warszawa 1990, pp. 22-25, 35; idem, Mit polityczny, Warszawa 1989, s. 331-339; M. Orzechowski, Polityka, władza, panowanie w teorii Maxa Webera, Warszawa 1984, pp. 269-291; S. Filipowicz, Mit i spektakl władzy, Warszawa 1988, pp. 133-134.
} 
political movement arisen on the basis of the charismatic factor should be transformed into a political actor - the fullest exponent of tradition.

Technocratic legitimation was the fourth form. It consisted in referring to the political skills of the dictator and his camp, which were confirmed by history. Propaganda presented the dictator's different personal merits: historic and praxeological. It was these meritorious services that became an important constituent of the leader's legend. Another manifestation of technocratic legitimation was the appeal by the ruling formation to the idea of elitism. The elite recruited by the dictator from among various social classes, professional circles and political groups would bring the necessary skills, thorough knowledge, and social moderation into politics. By contrast, these features were not attributed to society as a whole or to any selected social group.

In authoritarianism we can often witness the 'drama of legitimation', most often associated with the leader's death. The authoritarian camp was then faced with the problem of developing new forms of legitimation because the old ones were no longer relevant. Hardly ever was a new dictator appointed from among the associates of the deceased leader. Most often, the authoritarian system collapsed, or a totalitarian order was imposed (Central Europe during World War Two), or the process of democratization took place (in Western Europe in the latter half of the twentieth century). In the former case this meant having recourse to the idea of leadership, in the latter - the democratic formula of the legitimation of State power, based on election results, began to be used.

\section{LITERATURE}

[1] Biernat T., Fenomen władzy charyzmatycznej - ludzka potrzeba transcendencji (Refleksja antropologiczna), [in:] Antropologia polityki, z. 2, Warszawa 1990.

[2] Biernat T., Mit polityczny, Warszawa 1989

[3] Borejsza J.W., Mussolini byt pierwszy..., Warszawa 1979.

[4] Borejsza J.W., Szkoły nienawiści: Historia faszyzmów europejskich 19191945, Wrocław-Warszawa-Kraków 2000

[5] Brodzikowski W., Łoskoczyński J., Franco, generat wielkiej misji, Warszawa 1999.

[6] Bułhak H., Rola wojska w przewrotach autorytarnych, [in:] [w:] Dyktatury w Europie Środkowo-Wschodniej 1918-1939: Konferencja naukowa w Instytucie Historii PAN 2-3 XII 1971, ed. J. Żarnowski, WrocławWarszawa-Kraków-Gdańsk 1973.

[7] Car S., Na drodze ku nowej konstytucji, Warszawa 1934.

[8] Drąg Z., Mechanizmy zmiany systemów politycznych, "Zeszyty Naukowe Akademii Ekonomicznej w Krakowie”, Prace z Zakresu Nauk Politycznych 1998/500.

[9] Filipowicz S., Mit i spektakl władzy, Warszawa 1988.

[10] Górecki D., Pozycja ustrojowo-prawna Prezydenta Rzeczypospolitej i rządu W ustawie konstytucyjnej z 23 kwietnia 1935 roku, Łódź 1992

[11] Grzybowski K., Moderator imperii, "Czasopismo Prawno-Historyczne" $1963 / 2$.

[12] Grzybowski K., Od dyktatury ku kompromisowi konstytucyjnemu, Kraków 1930. 
[13]Holzer J., System faszystowski a autorytarny: Uwagi polemiczne, "Acta Universitatis Wratislaviensis", Studia nad faszyzmem i zbrodniami hitlerowskimi. Faszyzm - teoria i praktyka w Europie (1922-1945) 1977/3.

[14] Hołówko T., Ostatni rok, Warsaw 1932.

[15] Kochanowski J., Węgry: Od ugody do ugody 1867-1990, Warszawa 1997

[16] Koźmiński M., Nacjonalizm, mniejszości narodowe a reżimy dyktatorskie w Europie Środkowo-Wschodniej w latach 1918-1939, [in:] Dyktatury w Europie Środkowo-Wschodniej 1918-1939: Konferencja naukowa w Instytucie Historii PAN 2-3 XII 1971, ed. J. Żarnowski, WrocławWarszawa-Kraków-Gdańsk 1973.

[17] Królikowski W., Hiszpania 1923: Pronunciamento generała Primo de Rivery, [in:] Przewroty i zamachy stanu: Europa 1918-1939, ed. A. Garlicki, Warszawa 1981.

[18] Kumaniecki K.W., Nadzwyczajne urzędy (z prawniczych rozmyślań nad dyktatura), Kraków 1928.

[19] Lewandowski J., Historia Estonii, Wrocław-Warszawa-Kraków 2002.

[20]Linz J.J., An Authoritarian Regime: Spain, [in:] Cleavages, Ideologies and Party Systems, eds A. Allardt, Y. Littunen, Helsinki 1964.

[21] Łossowski P., Europa Środkowo-Wschodnia XX wieku - triumf dezintegracji?, "Dzieje Najnowsze" 1996/1.

[22] Łossowski P., Ideologie reżimów autorytarnych (kraje bałtyckie 1926-19341940), [in:] Dyktatury w Europie Środkowo-Wschodniej 1918-1939: Konferencja naukowa w Instytucie Historii PAN 2-3 XII 1971, ed. J. Żarnowski, Wrocław-Warszawa-Kraków-Gdańsk 1973, pp. 127-141.

[23] Łossowski P., Rzqdy dyktatorskie w państwach battyckich 1926-1940: Studium porównawcze, "Acta Universitatis Wratislaviensis", Studia nad faszyzmem i zbrodniami hitlerowskimi 1982/8.

[24]Machcewicz P., Frankizm: Analiza ruchu politycznego, "Magazyn Historyczny. Mówią Wieki” 1990/8.

[25] Mikołejko A., Poza autorytetem?: Społeczeństwo polskie w sytuacji anomii, Warszawa 1991.

[26] Misiuk A., Służby specjalne II Rzeczypospolitej, Warszawa 1998

[27] Mularska-Andziak L., Dyktatura generała Primo de Rivery a hiszpańskie tradycje imperialne 1923-1930, Warszawa 1999

[28] Orzechowski M., Polityka, władza, panowanie w teorii Maxa Webera, Warszawa 1984

[29] Paluszyński T., Walka o niepodległość Łotwy 1914-1921, Warszawa 1999

[30] Payne S.G., The Franco's Regime, Madison 1987.

[31] Piłsudski J., Pisma zbiorowe: Wydanie prac dotychczas drukiem ogłoszonych, vol. 9, Warszawa 1938.

[32] Poznańska K., Republika Turecka: Türkiye Cumhuriyeti, Warszawa 1977

[33] Rataj J., O autoritativní národní stát: Ideologické proměny české politiky v Druhé Republice 1938-1939, Praha 1997.

[34]Ryszka F., Państwo autorytarne, [in:] Dyktatury w Europie ŚrodkowoWschodniej 1918-1939: Konferencja naukowa w Instytucie Historii PAN 2-3 XII 1971, ed. J. Żarnowski, Wrocław-Warszawa-Kraków-Gdańsk 1973. 
[35] Ryszka F., Państwo stanu wyjatkowego: Rzecz o systemie państwa i prawa Trzeciej Rzeszy, 3 ed., revised and amended, Wrocław-Warszawa-KrakówGdańsk-Łódź 1985.

[36] Salazar A., Rewolucja pokojowa, Warszawa 2013.

[37] Schmitt C., Teologia polityczna i inne pisma, Warszawa 2012.

[38] Skarzyński R., Od chaosu do ładu: Carl Schmitt i problem tego co polityczne, Warszawa 1992.

[39] Sokół W., Legitymizacja polityczna, [in:] Wprowadzenie do nauki o państwie i polityce, eds B. Szmulik, M. Żmigrodzki, Lublin 2002.

[40] Sokół W., Legitymizacja systemów politycznych, Lublin 1997.

[41] Sokół W., System autorytarny i jego legitymizacja, [in:] Społeczeństwo Państwo - Władza, ed. M. Żmigrodzki, Lublin 1995.

[42] Sprawozdanie stenograficzne z 142 posiedzenia Sejmu Rzeczypospolitej [Shorthand report of the Sejm session, $3^{\text {rd }}$ term], 23/24 march 1935.

[43] Stanistaw Car - polska koncepcja autorytaryzmu, ed. J.M. Majchrowski, Warszawa 1996.

[44] Tomaszewski J., Czechostowacja, Warszawa 1997.

[45] Tuñón de Lara M., Baruque J.V., Ortiz A.D., Historia Hiszpanii, Kraków 1997.

[46] Voegelin E., Der autitäre Staat, Vienna 1936.

[47] Wielomski A., Doktryna El Caudillaje na tle XIX-i XX-wiecznej hiszpańskiej tradycji politycznej, "Acta Universitatis Wratislaviensis", Studia nad faszyzmem i zbrodniami hitlerowskimi 1999/22.

[48] Wituch T., Historia Portugalii w XX wieku, Pułtusk 2000.

[49] Wprowadzenie do nauk politycznych, M.G. Roskin et al., Poznań 2001

[50]Żarnowski J., Reżimy autorytarne $w$ Europie Środkowej i PoludniowoWschodniej w okresie międzywojennym - analogie i różnice, [in:] Dyktatury w Europie Środkowo-Wschodniej 1918-1939: Konferencja naukowa w Instytucie Historii PAN 2-3 XII 1971, ed. J. Żarnowski, WrocławWarszawa-Kraków-Gdańsk 1973.

[51]Żyro T., Autorytet a autorytaryzm: Kilka uwag doktrynalnych, [in:] Adaptacja - reforma - stabilizacja: Przestrzeń publiczna we współczesnych systemach politycznych, eds T. Koziełło, P. Maj, W. Paruch, Rzeszów 2010.

\section{AUTORYTARYZM W EUROPIE W XX WIEKU: POLITOLOGICZNA ANALIZA CECH SYSTEMU POLITYCZNEGO (CZEŚĆ 1)}

Artykuł jest analizą politologiczną autorytaryzmu jako systemu politycznego, alternatywnego dla demokracji i totalitaryzmu w XX wieku. Do tego celu zostało użyte pojęcie „syndrom autorytarny”. Zdefiniowano „syndrom autorytarny”, na który składa się siedem elementów kontytutywnych, występujących łącznie. Elementy zostały wydzielone w wyniku badań źródłowych konkretnych przypadków ustanowienia i funkcjonowania systemu autorytarnego w Europie Środkowej i Zachodniej. Są to: 1) suweren - podstawowa instytucja władzy państwowej; 2) zamach stanu - charakter, typ idealny, cechy charakterystyczne, warianty; 3) formuła legitymizacji władzy państwowej oraz "dramat legitymizacyjny" po śmierci dyktatora; 4) limitowana autonomia społeczeństwa w postaci jego depolityzacji oraz ochrony przed ingerencją państwa wydzielonych sfer życia społecznego; 5) konsolidacja władzy państwowej; 6) tradycyjny ład aksjologiczny; 7) obóz 
autorytarny. W części 1 artykułu omówiono cztery pierwsze składniki „syndromu autorytarnego". W autorytaryzmie za suwerena uznano państwo, którego interesy i podmiotowość były wyrażane przez dyktatora. Zamach stanu był przeprowadzany przez wojsko bez angażowania społeczeństwa, natomiast formuła legitymizacji władzy państwowej została oparta na roli politycznej i historycznej oraz kompetencjach dyktatora. Celem władzy w autorytaryzmie było zdepolityzowanie najważniejszych konfliktów społecznych i ekonomicznych.

Słowa kluczowe: autorytaryzm, system polityczny, XX wiek, myśl polityczna.

DOI:10.7862/rz.2014.hss.26

Przesłano do redakcji: maj 2014

Przyjęto do druku: lipiec 2014 